\title{
Togo Mizrahi, Work over Words
}

To usher in the new year, 1941, an Egyptian weekly magazine published a special issue devoted to the arts featuring interviews with high-profile figures. Togo Mizrahi, the successful and prolific film director, was quoted as saying, "No Egyptian actress is fit to stand before the camera." To stanch the furor over his remarks, Mizrahi penned a lengthy letter to the editor. The filmmaker's response to this embarrassing gaffe provides insights into Mizrahi's character and his place in Egyptian culture. $^{2}$

Togo Mizrahi was known to be media shy - a man who "prefers work over words." ${ }^{3}$ He granted few interviews, and had little experience dealing with the press. His response letter is one of the few surviving pieces Mizrahi published in the Egyptian press. While in his letter Mizrahi does not deny making the inflammatory statement, he accuses the journalist of distorting his words and taking them out of context. Mizrahi asserts that he had not intended to disparage any of the actors he had worked with. He claims, instead, that he wished to outline for emerging talent what it takes to launch a successful cinema career. ${ }^{4} \mathrm{~A}$ more mediasavvy director would have weighed his words more carefully.

The letter also reveals the two roles Mizrahi played in the Egyptian cinema industry. Mizrahi was one of the pioneers of the industry, founding a studio and a production company in 1929. He was also a prolific director of popular comedies and musicals. In his letter, Mizrahi speaks from his perspective as a director when he addresses his relationship with actors. He describes his pride in eliciting strong performances from actors-and the pride of actors when they see their work in the director's hands. But he also signals the importance of his relationships with actors from his perspective as "the director of a company." Mizrahi identified as both director and producer, artist and businessman.

But what is perhaps most striking about this letter is the way it demonstrates Mizrahi's centrality in the Egyptian film industry. One by one, Mizrahi directly addresses the lead actors who had appeared in his films to extol their virtues: Yusuf 
Wahbi, 'Ali al-Kassar, Sulayman Naguib, 'Abd al-Salam al-Nablusi, Amina Rizq, Dawlat Abyad, Layla Murad, Mimi Shakib, Zuzu Shakib, 'Aqila Ratab, and Salwa 'Alam. He also expresses his gratitude to Zakariya Ahmad and Riyad al-Sunbatitwo of the most prolific and acclaimed composers of Arabic music in Egypt at that time. The letter reads like a who's who of Egyptian cinema in the 1940 .

Togo Mizrahi played an important role in developing Egyptian cinema in the 1930 and 1940s. He was committed to producing quality, popular, and financially viable films. Beyond his own films, he was also committed to building a vibrant domestic cinema culture in Egypt. This chapter traces the arc of Mizrahi's career. I begin with Mizrahi's background, growing up in an elite Jewish family in Alexandria. I divide his career into two periods. In the first period, from 1930 to 1939, Mizrahi directed and produced films at the studio he founded in Alexandria. In this period, he produced melodramas and comedies that reflect a socially conscious Levantine cinematic idiom. In 1939, Mizrahi moved to Cairo, where he launched the second phase of his career with a big-budget musical.

Fortunately, Mizrahi suffered no significant, long-term consequences of his gaffe in 1941. For another five years, he continued to have a productive and celebrated career directing and producing films. Suddenly, in 1946, Mizrahi withdrew from the film industry. The final section of this chapter explores Mizrahi's departure from Egypt, the sequestration of his studio and production company, and his loss of the rights to his films.

\section{TOGO MIZRAHI, A JEWISH SON OF EGYPT}

Joseph Elie Mizrahi was born on 2 June 1901 in Alexandria. His parents, Jacques Mizrahi (1870-1935) and Mathilde Tawil (1875-1935), were Alexandria natives. ${ }^{5}$ Joseph was the third of eight children (fig. 4). The aristocratic Mizrahi family had made its fortune in the cotton and textile trade. ${ }^{6}$ Jacques worked in the management of the Alexandria Bonded Warehouse Company. ${ }^{7}$

Jacques's mother was a descendant of the influential Sephardi Aghion family that emigrated from what is now Italy to Egypt in the eighteenth century. ${ }^{8}$ When Mizrahi was born in 1901, his birth certificate was issued by the Jewish community of Alexandria, Egypt (Comunità israelitica in Alessandria d'Egitto), and certified at the Austro-Hungarian consulate.

Few Jews residing in Egypt in the interwar period held Egyptian nationality. Elite Egyptian Jews, among others, received protection, and in many cases nationality, by foreign consulates under the terms of Ottoman-era capitulations to European powers. ${ }^{9}$ Nationality among the elites of Alexandria sometimes bore little relationship to a family's origins or self-identity. As with other Egyptian Jews, the full story of the Mizrahi family's origins and their nationality are somewhat unclear.

In September 1919, the grand rabbinate of Alexandria reissued Joseph Mizrahi's birth certificate to supplant the original, which had borne an Austro-Hungarian consular stamp. In the aftermath of World War I, Sephardi Jews living in the 


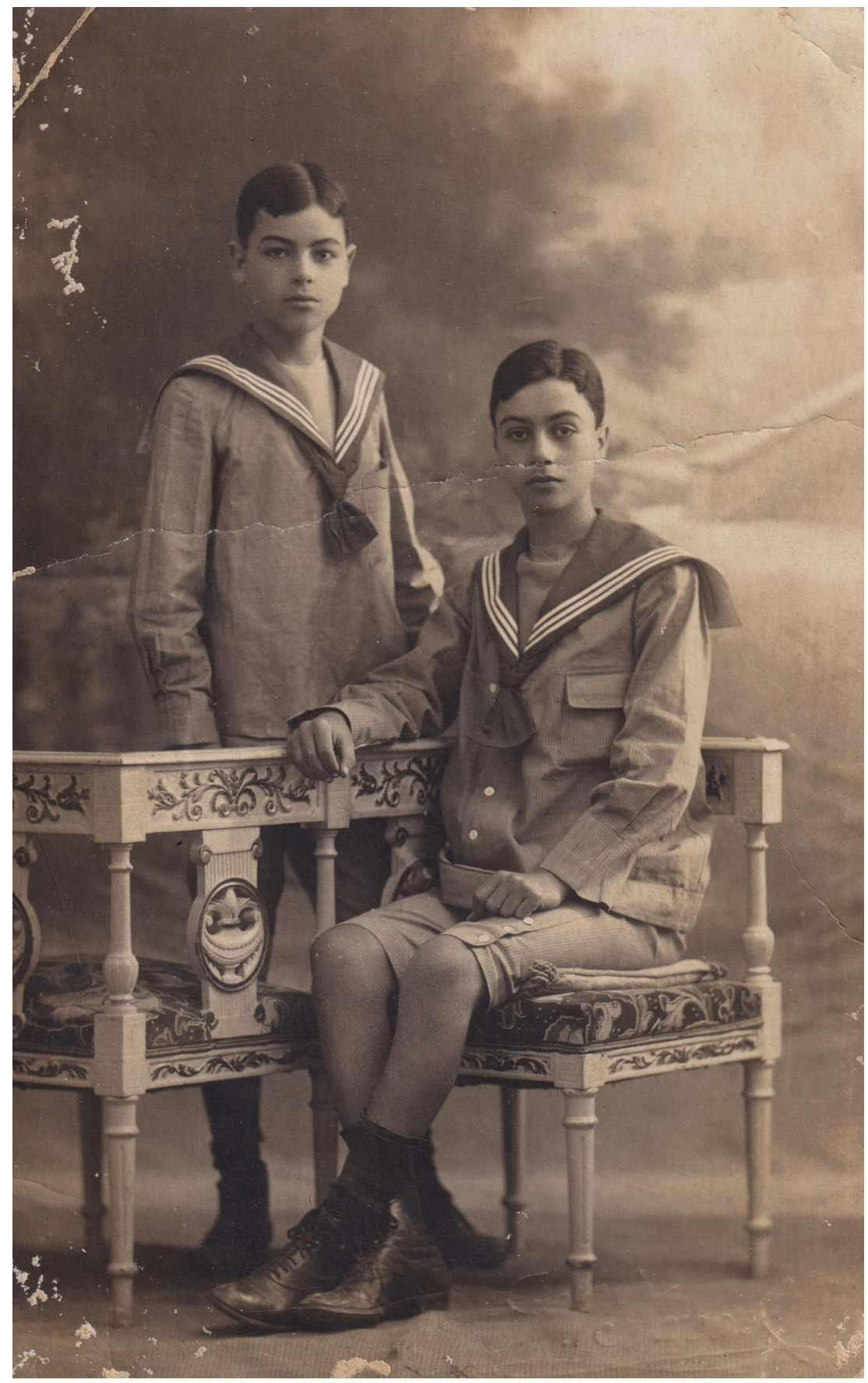

FIGURE 4. Togo Mizrahi (seated, right) with his brother, Félix, who later performed under the screen name 'Abd al-'Aziz al-Mashriqi. Circa 1915. Courtesy of Jacques Mizart. 
eastern Mediterranean with a connection to the Italian peninsula were granted limited rights as Italian citizens. ${ }^{10}$ Joseph, like his parents, held Italian nationality.

In his youth, Joseph became known by the nickname Togo, a reference to the decorated Japanese admiral Togo Heihachiro. One conjecture holds that Mizrahi's family adopted the name in 1905, following Admiral Heihachiro's great victory over the Russian Navy's Baltic Fleet at the battle of Tsushima. ${ }^{11}$ Mizrahi's nephew Jacques Mizart recalls his uncle saying that he personally chose to adopt the name out of admiration for Admiral Heihachiro. One can imagine how a boy who later chose a career that entailed ordering around actors, set designers, and camera operators may have become enamored-or associated by his family-with a decorated military leader. A birth certificate reissued in 1920 lists his name officially as Joseph Elie Togo Mizrahi. From that point on, the name Togo appears on his official documents. ${ }^{12}$

Growing up in the Bulkley district of Alexandria, Mizrahi was educated at the Lycée français, completing his studies in 1919. ${ }^{13}$ Between 1920 and 1922 Mizrahi studied at the École des hautes études commerciales in Lyon. He continued his studies in Milan, receiving a diploma in commerce in $1925 .{ }^{14}$ During his summer vacations, and then after completing his studies, Mizrahi gained experience working for Jewish-owned businesses in Alexandria: J. Rolo \& Co. (1921-25); ${ }^{15}$ and Aghion Frères (1925-26). ${ }^{16}$

THE MAKING OF THE “TOGO CINEMA FAMILY”:

ALEXANDRIA, 1929-1939

During the late 1920s, Togo began to build his skills as a filmmaker. He visited and apprenticed at studios in France and Italy, among them, Gaumont Studios. ${ }^{17}$ In Paris, Togo met Abel Gance, who invited him to the set of La fin du monde (The End of the World, 1931). ${ }^{18}$ Mizrahi began by shooting short films, newsreels, and advertisements in Rome and Alexandria. ${ }^{19}$ Mizrahi appears to have signed a contract with a distributor for the short films he shot while in Europe. ${ }^{20}$

Togo Mizrahi began his career as a narrative filmmaker by staging scenes featuring members of his family. Togo's youngest brother, Alfred, recalls: "At the beginning, he didn't have a studio. He would make short silent films, shooting them at our home. My sisters would give him jewels and accessories when he needed them." ${ }^{21}$

In 1929, Mizrahi set his sights on establishing a studio in Alexandria to produce feature films. One source suggests that Jacques Mizrahi, who expected his son to enter the world of commerce or finance, objected to Togo's plans to become a filmmaker and refused to support him. ${ }^{22}$ Togo's brother Alfred recalls otherwise, stating that Jacques, who died in 1935, was very proud of his son's success as a filmmaker. ${ }^{23}$ The Behna family - who had already begun to develop commercial interests in the film industry-provided Togo Mizrahi with a loan. ${ }^{24}$ With this assistance, in 1929 
Togo Mizrahi converted a cinema on Hajar al-Nuwatiyya Street, in the Bacos neighborhood of Alexandria, into a fully functioning film studio with a stage, editing room, projection room, and laboratory. Mizrahi also founded a production company, Sharikat al-aflam al-misriyya, also known as the Egyptian Films Company.

Even after establishing the studio, Togo continued to cast friends and family members in his films. Togo's brother Félix starred in Al-Hawiya, al-kukayin (The Abyss, or Cocaine, 1930) and Awlad Misr (Children of Egypt, 1933) under the screen name 'Abd al-Aziz al-Mashriqi. ${ }^{25}$ Togo took a turn acting under the screen name Ahmad al-Mashriqi, playing supporting roles in Al-Bahhar (The Sailor, 1935), Children of Egypt, and Al-Duktur Farhat (Doctor Farahat, 1935). ${ }^{26}$ Togo's first sound film, Children of Egypt, was a true family affair: Togo's brother Félix played the lead role of Ahmad; Celine (Nina) Mizrahi, Togo's sister, appeared as Ahmad's sister; and Togo played the role of Husni, Ahmad's friend. Neither of Togo's siblings had any formal training as actors. When he was not appearing before the camera, Félix worked as a supervisor at the port of Alexandria. The script for Children of Egypt called for Félix's character to go crazy. According to family lore, in order to elicit the desired performance, Togo locked his younger brother in a garage for over an hour prior to filming. ${ }^{27}$

Other family members later worked in the production of Mizrahi's films. Togo's youngest brother, Alfred, started working at the studio in 1939, and held a number of positions ranging from accountant to production director. In addition to their long-standing, productive working relationship, Togo and Alfred were particularly close; when their parents, Jacques and Mathilde, died in 1935, Alfred went to live with Togo. ${ }^{28}$ Alfred received his first screen credit in 1941 as an assistant on the set of Al-Fursan al-thalatha (The Three Musketeers). By the time Layla was released the following year, Alfred had been promoted to managing director. Two of Togo's brothers-in-law also worked for the Egyptian Films Company. Togo's sister Celine married their first cousin, Clément (Sulayman) Mizrahi, who is credited as the general manager of the company during the production of Layla mumtira (A Rainy Night, 1939). Togo's sister Leila married Zizo (Isaac) Ben Lassin, who is identified as the studio director in the production of Layla (1942).

In 1930, as he was launching the production of his first feature film, Mizrahi sought the expertise of cinematographer Alvise Orfanelli, who had trained in photographic technique in the studio of 'Aziz Bandarli and Umberto Dorés. ${ }^{29}$ Orfanelli launched his cinematographic career in 1919 with the silent short Madame Loretta, directed by Leonard Laricci and staring Fawzi al-Gazayirli. By the time he signed on to work with Mizrahi on The Abyss, or Cocaine, in 1930, Orfanelli had already shot six films, and had established his own lab and studio. The collaboration between Mizrahi and Orfanelli continued over four films between 1930 and 1934 .

In 1935, as Mizrahi was preparing to shoot Doctor Farahat, he paid Orfanelli a visit to contract his services again. Orfanelli was already committed to a project, however, so Mizrahi asked about the availability of 'Abd al-Halim Nasr, his 
assistant camera operator. Nasr had recently parted ways with Orfanelli following a dispute over wages. Orfanelli nevertheless provided Nasr with a certificate attesting to his expertise in the film studio and lab. Outside, Mizrahi ran into Nasr, who described the encounter as follows: "I felt a hand tap me on the shoulder with compassion. I turned around to see Togo Mizrahi. Togo knew me because I had shot one of his films while I was working with Orfanelli." ${ }^{\circ \circ}$ Nasr continues: "I handed him the certificate that Orfanelli had given me. He read it quickly and said to me, 'So we've agreed. I went there to come to an agreement with you about some work. So long as I found you, we have an agreement.' And he put his hand in his pocket and handed me thirty Egyptian pounds as payment. He said it was support for three months." ${ }^{31}$ Mizrahi then continued, "After I return from Europe I will call for you, and we will start work right away." ${ }^{2}$

Nasr had reportedly left Orfanelli's studio when he was refused a two-pound raise, from seven to nine Egyptian pounds per month..$^{33}$ Mizrahi's initial offer not only put Nasr on retainer for the three months before shooting started, but also exceeded his requested salary increase. The collaboration between 'Abd al-Halim Nasr and Togo Mizrahi was very successful and enduring. 'Abd al-Halim Nasr served as cinematographer on all but two of the films Togo Mizrahi directed from 1935 to $1945 .{ }^{34}$ This collaboration launched 'Abd al-Halim's prolific, decades-long career as a respected cinematographer.

'Abd al-Halim's brother Mahmud also came to work in Mizrahi's studio in 1935. In an interview, Mahmud provides insights into the workings of Studio Mizrahi at that time: "They were preparing for a film called Doctor Farahat that Togo Mizrahi was directing. He left the filming to 'Abdu ['Abd al-Halim] Nasr, and I worked as his assistant. As an assistant cameraman, I received a salary in the amount of two Egyptian pounds per month, as well as a free pass to ride the tram. ... In addition, as an assistant for lighting, editing, lab, and display, I was able to see what we had filmed." 35 According to Mahmud Nasr, Mizrahi's production team in the mid-193os amounted to three people-the brothers 'Abd al-Halim and Mahmud Nasr, and Togo himself - with everyone taking on multiple roles in mounting a production (fig. 5). Mahmud describes the labor of film production in Studio Mizrahi during this period:

We would undertake, the three of us, all of the work, from sweeping the studio to carpentry and the construction of décor and lighting, and perpetually improve upon it until we began shooting the film under Togo's direction, and with Togo's guidance. After the completion of every reel, my brother 'Abd al-Halim or I would carry it on the Ramleh tram to Studio Alvise [Orfanelli's studio] for developing, printing, and editing. ${ }^{36}$

Togo Mizrahi treated filmmaking like a family affair, forging close professional ties with his creative partners and business associates. Filmmaker Ahmad Kamil Mursi, who got his start at Studio Mizrahi, referred to Mizrahi's production team as "the Togo cinema family." ${ }^{77}$ Even as his productions expanded, Mizrahi 


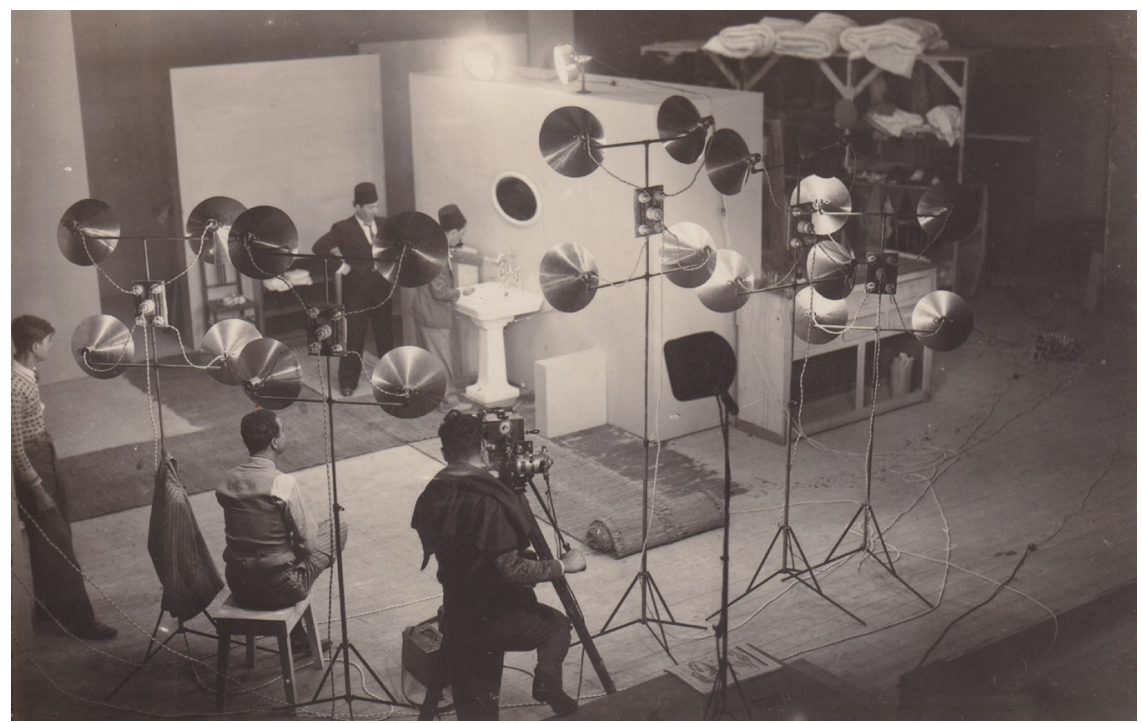

Figure 5. Togo Mizrahi (seated) on the set of The Two Delegates (1934). Courtesy of Jacques Mizart.

continued to work with the same team, which grew to include set designer 'Abd al-Hamid al-Shakhawi, lab technician Ridwan 'Uthman, production director 'Abd al-Hamid Zaki, and assistant director Ibrahim Hilmi. Ahmad Kamil Mursi, who also cut his teeth at Studio Mizrahi, claims that the group, the "Togo cinema family," was connected by "strong bonds of loyalty, love, and passion for work and life." Mursi elaborates: "Togo always took care to collaborate with a close circle of technicians and artists who worked in most of his films throughout his career and whose names were afterward to be associated with Mizrahi's." ${ }^{38}$

In his Alexandria studio between 1930 and mid-1939, Togo Mizrahi directed seventeen films - two silent films, eleven Arabic sound films, and four sound films in Greek. ${ }^{39}$ During those years, Mizrahi's production company, the Egyptian Films Company, produced two additional films that were shot at Studio Mizrahi but that Togo did not direct.

\section{Creation of a Socially Conscious Levantine Idiom}

Togo Mizrahi's films produced in his Alexandria studio between 1930 and 1939 represent the struggles of the lower classes. Mizrahi broke onto the cinema scene in Egypt in 1930 with his debut feature, The Abyss, or Cocaine. The film delivered a powerful warning about the ill effects of drug addiction, contributing to an ongoing, centralized public-relations and educational effort in Egypt at the time

The trafficking, production, and use of white drugs-cocaine and heroin-rose in Egypt following World War I. By the mid-1920s, Sir Thomas Russell (Russell Pasha), the Cairo chief of police, spearheaded a campaign against white drugs. 
On the international front, in 1929 Russell Pasha participated in a delegation to the League of Nations that appealed for the intervention of international law. The same year on the home front, Russell Pasha established the Central Narcotics Intelligence Bureau (CNIB) to combat the drug trade. In addition to the extensive press campaign documented by Liat Kozma, ${ }^{\circ}{ }^{\circ}$ Russell also directly encouraged and supported dramatic representations discouraging drug use.

The Egyptian press avidly covered the production of a film commissioned by the ministry of the interior titled Al-Mukhadarat (Drugs). ${ }^{41}$ By early 1930, director Hasan al-Halbawi had brought in sound specialists and modern equipment to record the film as a talkie, and some of the footage was shot on location in the desert. It is unclear if this big-budget, government-funded extravaganza was released in theaters. ${ }^{42}$

On 16 May 1930, after shooting for the ill-fated film Drugs had concluded, Russell Pasha attended a performance of an antidrug play titled Al-Kukayin (Cocaine) in Cairo. The play, written by Vedat Örfi, was performed by Yusuf Wahbi's troupe at the Ramsis Theater during the 1929-30 season. Following the performance, Russell Pasha stood up before the audience, shook the playwright's hand, and commended him for his great public service. The following day, Russell Pasha published a notice in the press publicly thanking Örfi and the Ramsis troupe for their contribution to the fight against drug use in Egypt. ${ }^{43}$

In February 1931 during Eid al-fitr, the Ramsis troupe reprised their production of Örfi's play Cocaine for a matinee performance. ${ }^{44}$ The previous evening, Togo Mizrahi's similarly titled feature film, The Abyss, or Cocaine, premiered in Cairo at the American Cosmograph Cinema. To confuse matters further, the film shares a title with another play, Muhammad Taymur's Al-Hawiya (The Abyss), written in 1920. Taymur's play The Abyss had been revived in the prior season, also by the Ramsis troupe, but publicity for the 1929-30 production of Taymur's play lists it under the title Al-Mukhadarat (Drugs), the same title as the ill-fated film directed by al-Halbawi. ${ }^{45}$ All these confusing titles aside, it is safe to say that Togo Mizrahi's premier feature, a drama of "the abyss where so many unfortunate souls drawn to harmful drugs debase themselves," inserted itself into an already dense field of artistic efforts to combat drug use. ${ }^{46}$

In Mizrahi's film The Abyss, or Cocaine, Ahmad, a laborer, is married and has a young son. Hasan, a compatriot, falls in love with Ahmad's wife. Hasan tries to get Ahmad out of the way by introducing him to drugs. Ahmad becomes addicted and loses his job. After Ahmad's wife goes to work as a laundress, things deteriorate even further. When she refuses to give Ahmad money she has set aside to buy food, he kills their son. He is arrested, tried, and sentenced to death for his crime. The evil Hasan, too, gets his due: in an obvious parallel to Ahmad's death on the gallows, Hasan falls off a scaffold at a construction site and dies. ${ }^{47}$

The Abyss, or Cocaine is pitched to attract both Egyptian and European audiences. The program praises the performers for their "powerful" and "naturalistic" acting that will "satisfy even the most exacting critic," and hails the film for its 
universal appeal, calling it "the most powerful film on cocaine use to this day." The cinema program also vaunts the film's local authenticity, inviting viewers to identify familiar urban landscapes depicted in the film:

Everyone, without exception, must see this impressive drama that destroys an Egyptian family. The life of a worker is picturesquely reproduced in its smallest details with a genuine sincerity and a poignant truth.

In contrast to all other Egyptian films shown to this day, the action of this film does not take place in the countryside, but in the heart of the city, the sites with which we are familiar, making the film the truest, and most successful one that you will ever see. All Egyptians and Europeans alike will appreciate the very real and very powerful value of this good film, with its lifelike portrayal of such a burning issue..$^{48}$

The program stresses the film's authenticity-using no fewer than five synonyms for its depiction of reality. Although there is no pretense that the plot of this social melodrama is based on actual events, the film is billed as truth.

One of Mizrahi's earliest collaborators, Leon Angel, best known by his screen name, Chalom, reportedly drew on his family experience to help develop the scenario for the film. ${ }^{49}$ According to colorful family lore, Angel's father had smuggled hashish on the Nile. In 1929 Russell Pasha conceived of the idea of holding a competition for the best screenplay "combatting deadly white drugs," to be underwritten by the Ministry of the Interior. ${ }^{50}$ Angel reported that The Abyss, or Cocaine won this competition. According to Angel, he and Mizrahi used the prize money to support the production of their next film..$^{51}$

Togo Mizrahi's film The Abyss, or Cocaine was moderately successful on the first run, ${ }^{52}$ returning for a weeklong second run in Cairo at Cinema al-Ahli in April 1932 during Eid al-Adha..$^{53}$ The return of Cocaine, The Abyss also coincided with the Cairo premier of Mizrahi's second feature, 05001, at the Egyptian-owned and-operated Cinema Olympia on 11 April 1932. Holidays were a particularly popular time for both live performances and film releases. Four Egyptian films played at cinemas in Cairo in April 1932 during Eid al-Adha. In addition to Mizrahi's two films, Mario Volpe's Anshuda al-fu'ad (Songs of the Heart) premiered at Cinema Diana Palace on 14 April,,$^{54}$ and Muhammad Karim's Awlad al-zawat (Children of the Aristocracy) returned for a second run, at Cinema Metropole (following a two-week premier showing at Cinema Royal) .55 It is noteworthy that, at the outset of Mizrahi's film career, his first two feature films commanded prime place at two cinemas in Cairo during a major holiday, when the local populace had leisure time to take in a movie.

Little is known about 05001, and the film is unavailable. Billed as a sports comedy, the film featured Chalom (Leon Angel) and Dawlat Ramzi, along with an actor identified as Hasan Muhammad 'Abdu..$^{56}$ Muhammad Awad and Sahar Hamouda offer the following synopsis: "By a stroke of luck Shalom wins lottery ticket number 05001 and becomes rich. Rather than bring him happiness, this wealth causes him trouble. He therefore goes back to his old way of life." ${ }^{57}$ 
Mizrahi's third film, Awlad Misr (Children of Egypt), was his first sound film production. Children of Egypt, which premiered on 6 April 1933 at Cinema Lido al-Watani in Alexandria, is a social melodrama featuring a love story between a poor student and the daughter of a wealthy man. Ahmad (Félix Mizrahi, credited as 'Abd al-'Aziz al-Mashriqi) strives to overcome class disadvantage through his academic success. Ahmad befriends another engineering student, Husni (Togo Mizrahi, credited as Ahmad al-Mashriqi), who hails from a wealthy family. Ahmad falls in love with Husni's sister Dawlat (Ginan Raf'at). Ibrahim, Dawlat's cousin, who wishes to marry Dalwat himself, conspires to turn her against Ahmad. Following Dawlat's rejection, Ahmad lands in a mental hospital. When Dawlat learns of her cousin's betrayal, she rushes to Ahmad's side. Ahmad recovers and the two wed. ${ }^{58}$ Critic Mahmud Ali Fahmi identifies in the film a strong undercurrent of sympathy for the Egyptian lower classes: “Togo Mizrahi chose to make the poor boy a genius in his studies. He succeeds on his own merits; he does not make it the way the rich kids do." 59

Mizrahi's films from the mid to late 1930 s continued to direct attention to lower-class concerns. Many of these films are comedies of mistaken identity that also evince a culture of coexistence that cuts across class. Mizrahi's choice of stars for these films reflects an inclusive vision of local subjectivity. Mizrahi made multiple films featuring the same three comic actors, who consistently portrayed lower-class characters: Chalom, who played a Jewish character; 'Ali al-Kassar, who played a Nubian character; and Fawzi al-Gazayirli, who played urban Egyptian characters. Mizrahi's films from this period also regularly feature Greek and shami (i.e., Levantine Arab) characters as well as members of the francophone Alexandrian elite. During this period, Mizrahi established a distinctive perspective in his films-what I call a Levantine cinematic idiom. The features of this Levantine idiom, as outlined in the introduction and discussed at greater length in the next three chapters, are an ethics of coexistence, an aesthetic of inclusion, and a construction of identity as fluid and mutable. ${ }^{60}$

\section{Critical Reception of Togo Mizrahi's Films}

Over the course of his career, Mizrahi earned the respect of Egyptian film critics and industry professionals. He was widely lauded for his active participation in building an Egyptian national film industry. But in the early years, the Cairo-based national press was somewhat slow to notice the output of Mizrahi's Alexandria studio. As the production in Mizrahi's Alexandria studio increased, his films began to garner the attention of the press. In 1935, a reporter for Al-Ithnayn set out from Cairo to interview Togo Mizrahi about his forthcoming release, Doctor Farahat:

Considering the success Togo Mizrahi achieved with his last feature, The Two Delegates, when I learned that he would soon release his new feature, I went to the studio in Bacos to obtain an interview for this magazine. 
The man met me with his face overflowing with joviality and geniality. Without leaving me time to ask him a question, he rushed to say, "I learned, before all else, that I detest commotion and false advertising. In my view, when film is good and strong, it will definitely capture the audience and compel them to rush in to see it, rather than waiting for the second or third run."

That is the opinion of Ustaz Togo. Following his advice, in promoting the film we will hold fast, and we will not reveal here any details that would give the public any idea about the story of Doctor Farahat. The public can judge in favor or against it. The reader may know in advance that the film was produced by Studio Mizrahi in Bacos. The studio is full of technical instruments, and the system and precision of workmanship are pervasive. ${ }^{61}$

Mizrahi's aversion to self-promotion, and his reluctance to court the press, persisted throughout his career. In 1939, a critic for Al-Ithnayn wa-l-Dunya observed, "Togo Mizrahi, the director, is a man who works quietly for years without much fanfare, producing film after film with equanimity and mastery." ${ }^{62}$

While Togo Mizrahi preferred to avoid the limelight, he had a reputation in the industry as a "competent and skilled filmmaker." ${ }^{3}$ He was known as a consummate professional who worked methodically; one critic noted that he "does not improvise but rather proceeds by taking steps along the correct path." ${ }_{4}$ To maintain top performance, Mizrahi did not overtax his production team, filming for around five hours per day. ${ }^{65}$ Contemporaneous critics regularly credited Mizrahi with producing well-constructed, high-quality films. ${ }^{66}$ Some even hailed Mizrahi as a "genius," 67 "an amazing director," ${ }^{68}$ and "one of the best cinema producers in Egypt." 69

Critics at both Al-Sabah and Al-Ithnayn wa-l-Dunya credit the success of Mizrahi's films to their marriage of artistic merit and "popular spirit."7o A critic writing in 1936 for Al-Sabah elaborates: "Upon watching one of his films, one leaves the cinema hall with a good impression, whether you are a film critic (invested in looking for drawbacks and weaknesses in the film for which you may attack both the film and its maker) or a common spectator looking only for entertainment and recreation. This, in our opinion, is one of the reasons his films are generally successful." ${ }^{71}$

In the 1930s, Mizrahi came to be associated with a particular form of comedy, "punctuated by lots of humorous misunderstandings, as well as clever dialogue and innovative jokes." ${ }^{22}$ Critics also noted the social awareness of Mizrahi's comedies, and not just in his early social melodramas. Togo Mizrahi's film Ana tab $i$ kidda (It's My Nature, 1938) was, for example, lauded for inaugurating "a new world in local cinema production, the world of sophisticated comedy, which dramatizes the maladies of the society in a humorous manner and in meaningful joking far removed from vulgarities." ${ }^{33}$

While critical reception was generally positive, some complained that Mizrahi 's comedies engaged in "excessive exaggeration." 74 Mizrahi's comedies sometimes 
pushed the boundaries of good taste, and reviewers would call him out when he went too far. For example, in an otherwise positive review, of 10o,ooo gineh (One Hundred Thousand Pounds, 1936), one critic balks at one scene's overt sexual suggestiveness, advising that Mizrahi use greater restraint and leave more to the viewer's imagination..$^{75}$ Notwithstanding these criticisms, throughout Togo Mizrahi's career, his work as both director and producer was generally warmly received by the Egyptian press.

Studio Togo Mizrahi was admired for its state-of-the-art equipment-supplied and updated by Mizrahi during his regular travel to Europe. ${ }^{76}$ Critics welcomed the studio's prolific output.77

Despite this positive reception and his studio's productivity, through the 1930 s Mizrahi's films produced in Alexandria received relatively less media attention than those produced in Cairo by his peers. The press avidly covered every detail of film production at Studio Misr, from the earliest whispers of a new project and contract negotiations with actors to reviews and postrelease coverage of the films' popularity. Likewise, when Assia Dagher's Lotus Films began a new project, notices would appear in the press, accompanied by the occasional tantalizing promotional photograph taken on the set. As the release date approached, the weeklies would publish features about the film, and interviews with Assia Dagher (producer / lead actor), Ahmad Galal (director / lead actor), and Mary Queeny (supporting actor). The press also followed every new development in the career of Cairo-based director Muhammad Karim. Karim was regularly interviewed in the press-not only about his own films, but also about the state of the Egyptian cinema industry in general; during the 1934-35 season, he penned a regular weekly column for Al-Ithnayn.

There is no evidence that Mizrahi's nationality or religion had a significant negative impact on the critical reception of his films. Ahmad Kamil Mursi alludes to the circulation of prejudicial gossip about Mizrahi but claims that he was ultimately judged by his peers on the quality of his work: "Due to his religion, people never spared him from gossip. Yet his great work and success would silence his enemies, leaving them no pretext to attack him with slander." ${ }^{78}$

During the period in which the Egyptian film industry was becoming established, Togo Mizrahi was hailed for his contributions to this nationalist endeavor. He produced popular fare for an Egyptian audience. In the Egyptian press throughout the 1930s, Togo Mizrahi was granted the honorific "ustaz," thereby implicitly according him insider status; had the press wished to call attention to his religion or foreign nationality, they could have instead employed the honorific "khawaga."

By contrast, there had been some debate from the late 1920s through the mid1930 as to whether the Hollywood-inspired Orientalist fantasy films by the Lama brothers should be considered Egyptian. ${ }^{79}$ The Chilean-born Palestinian Ibrahim Lama settled in Egypt, along with his brother Badr (Pedro) Lama, and together they became pioneers of the Egyptian film industry. Ibrahim directed and Badr starred in one of the earliest silent features produced in Egypt, Qubla fi al-sahra' 
(A Kiss in the Desert, 1928). But six years later, a review of their sixth film, Shabah al-madi (Ghost from the Past, 1934), revisits the debate. Although the review, in effect, puts the question to rest by conclusively determining that the film should be considered Egyptian, the article nevertheless indicates that the debate was still alive. ${ }^{80}$ Set in the poorer districts of Alexandria, Togo Mizrahi's 1930 s comedies, many of which adapted the personae of popular comic stage actors to the screen, never faced such critical scrutiny in the press.

A number of factors seem to have deterred greater press coverage of Studio Mizrahi and its productions. As already noted, some directors embraced their roles as public figures. Mizrahi preferred to keep a low profile. After Mizrahi demurred to be interviewed by Al-Ithnayn in 1935, the magazine ceased prerelease coverage of his films. ${ }^{81}$ In addition, other major studios spent more on advertising than Studio Mizrahi: Assia Dagher's Lotus Films took out teaser campaigns, and the Lama brothers' Condor Films often bought multipage spreads in the weeklies to advertise a new release; the independent studios were all surpassed by the splashy advertising campaigns undertaken by Studio Misr. Advertisements for Studio Mizrahi films were, on average, of smaller size and ran for shorter duration than those promoting films by these three other studios. The popular weeklies may well have given greater coverage to the films with larger advertising budgets. Togo Mizrahi's reluctance to be interviewed, his resistance to hype, his studio's location in Alexandria, and his advertising budget all contributed to his relative marginalization by the press in the 1930s, despite his warm critical reception.

\section{“THE DIRECTOR WHO DOES THE EGYPTIAN FILM INDUSTRY PROUD": CAIRO, 1939-1946}

Togo Mizrahi's visibility in the press increased significantly following his move to Cairo in 1939. The staff of Mizrahi's Alexandria studio, members of the "Togo cinema family," made the move to Cairo with him. ${ }^{82}$ At this time, Mizrahi also reorganized the company. In the early years, Mizrahi benefited from the financial support of business partners. Effective the end of 1939, Mizrahi announced that he had become the sole proprietor of the Egyptian Films Company. ${ }^{83}$ Mizrahi leased studio space owned by Isma il Wahbi, the brother of actor Yusuf Wahbi, on 4 Husni Street in Giza. ${ }^{8}$ Over time, as his production needs increased, Mizrahi added a second sound stage to the studio. ${ }^{85}$ Mizrahi also reportedly bought land in Giza and built his own studio. ${ }^{86}$

Following the move, the character of Mizrahi's films shifted. Mizrahi began to explore new genres and comedic idioms. In addition to contemporary socially conscious Levantine farces, Mizrahi added bourgeois pastoral comedies, like Tahiya al-sitat (Long Live Women, 1943). In the 1940s Mizrahi also began to branch out into what could be called costume comedies, like the films starring 'Ali al-Kassar based loosely on narratives from the Thousand and One Nights: Alf Layla wa-Layla (One 
Thousand and One Nights, 1941) and 'Ali Baba wa-l-arba'in harami (Ali Baba and the Forty Thieves, 1942). Mizrahi also began making big-budget musicals featuring high-profile stars, including Layla Murad and Umm Kulthum. Like his Levantine comedies, his musical melodramas engage with social inequality. Mizrahi's musical films were among many cross-class romances that became popular in the 1940 s. $^{87}$

The films Mizrahi directed in the 1940s were the most popular and successful films of his career, receiving high praise from critics and audiences alike (fig. 6). Mizrahi also earned the respect of colleagues in the film industry. Famed musician and film star Muhammad 'Abd al-Wahab and rising filmmaker Ahmad Badr Khan publicly voiced their admiration for Mizrahi's 1941 film Layla bint madaris (Layla the Schoolgirl). ${ }^{88}$ After wrapping production on Long Live Women in 1943, actor Muhammad Amin penned a column praising Mizrahi's personal qualities and professional ethic, calling him the consummate artist. ${ }^{89}$

Film critics also held Mizrahi in high regard. In 1942, the Association of Cinema Critics voted Togo Mizrahi the most accomplished filmmaker in Egypt. ${ }^{\circ}$ The association represented critics employed by both daily and weekly Egyptian publications. Muhammad Karim, a highly celebrated director, came in second. By the time this vote was taken, Karim had directed eight features, including five high-grossing films starring singer Muhammad 'Abd al-Wahab. An earlier film by Karim, Awlad al-zawat (Children of the Aristocracy, 1932), was celebrated as the first Egyptian talkie. Today, Karim is regarded as one of the pioneers of Egyptian cinema; Mizrahi has largely been marginalized. But in 1942, professional cinema critics held Mizrahi in higher regard than Karim. The vote wasn't close. Mizrahi won by a landslide, beating out Karim by a margin of more than two to one. ${ }^{91}$

This admiration is expressed qualitatively as well; in the press, critics often associate Mizrahi with the terms "pride" and "honor." In 1942, a critic for the daily newspaper Al-Ahram proclaimed: “Togo Mizrahi's name has become synonymous with excellence-the director who does the Egyptian film industry proud." 92 The following year, Al-Sabah devoted a two-page spread to celebrate Mizrahi's innovations, accomplishments, and successes. The article claims that he goes to such extreme efforts as director, producer, and writer not for self-aggrandizing reasons, but rather so that the film industry will take pride in him. Yet even in the limelight, he maintains his characteristic humility: "[N]either in private meetings nor in the promotion of his films will he speak of himself. These are qualities of the consummate artist." ${ }^{93}$ Another article echoes these sentiments: "[Mizrahi] has always sought to improve the state of the film industry in Egypt. He was able to achieve that goal, bringing honor to [the industry], as he has brought honor to himself. No director or producer surpasses him." 94

Audience members also published letters of appreciation. Mizrahi's collaborations with singer Layla Murad, who was also Jewish, were especially warmly received in the Egyptian-Jewish press. Marco Ibrahim Cohen, a reader of the Arabic-language Jewish weekly Al-Shams, deemed Layla the Schoolgirl "a 


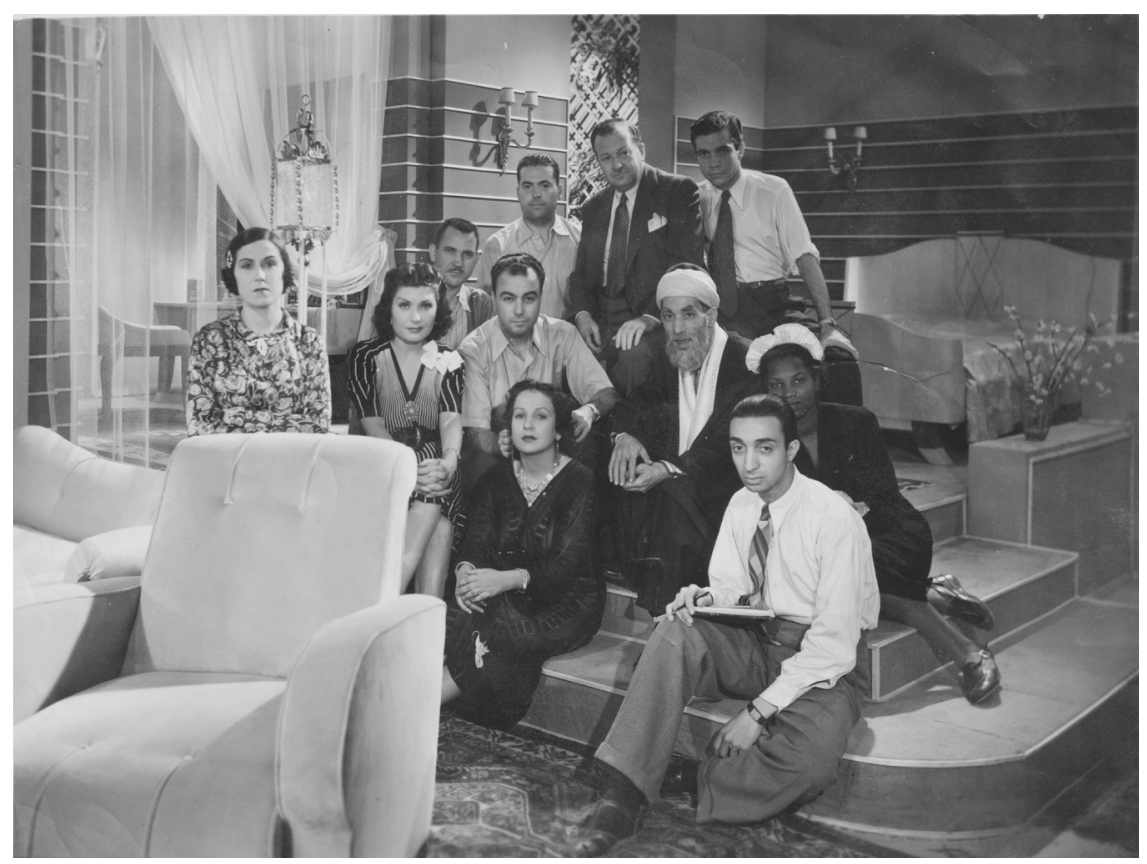

FIGURE 6. Togo Mizrahi (center) with the cast and crew on the set of Layla the Country Girl (1941). Courtesy of Jacques Mizart.

masterpiece." ${ }^{95}$ Another, anonymous reader of the newspaper wrote in as well to congratulate Togo Mizrahi on the film's "dazzling success": "The success of Layla the Schoolgirl is attributable both to the mastery of its director, Mr. Mizrahi, as well as to the performance of film and music stars Yusuf Wahbi and Layla Murad. ${ }^{96}$ "Mizrahi's films," he concludes, "are epitomes of creativity, and their success is unrivaled." ${ }^{97}$

Not all of his films were hits, of course. Following harsh criticism of the comedy One Thousand and One Nights, Mizrahi published a response. Striking a selfdeprecating tone, Mizrahi casts aspersions on all of his films, writing, "All of my films are nothing!":

In my opinion, all the films I have produced are nothing. This is my consistent opinion, as everyone who comes into contact with me knows-workers, employees, and actors, etc. Yes! Layla the Country Girl-nothing. One Thousand and One Nightsnothing. Layla-double nothing. That is my personal view. But does my opinion have any bearing on revenues at the cinema? Absolutely not! Because the audience has the first word and the final say. ${ }^{98}$

Mizrahi continues that what is holding Egyptian filmmakers back from producing films that could rival those made in Europe or Hollywood is not financing per se, but an overreliance on ticket sales. Cinemas' conservative impulses 
harm the industry by demanding more of the same. He accuses cinemas of having too much control over what gets screened-and what genres, topics, and stars will sell tickets. Adding insult to injury, cinemas take too large a cut of boxoffice revenue. ${ }^{99}$

Mizrahi, like other directors in Egypt at the time, distrusted and criticized the practices of cinema owners. Even as the domestic industry expanded in the 1940s, cinemas remained reluctant to screen Egyptian films. In spring 1945, cinema producers pressured the government to intervene. Seven major first-run theaters in downtown Cairo were compelled by the Ministry of Social Affairs to screen an Egyptian film one week per year. ${ }^{100}$

Even those cinemas that screened Egyptian films engaged in questionable practices. Take, for example, an incident from 1940. Cinema Cosmo-which was committed to screening Egyptian films - contracted with Assia Dagher to exhibit Fata mutamarrida (Rebellious Girl, Ahmad Galal, 1940) for five weeks, stipulating that if the film earned enough revenue, the engagement would extend to a sixth week. But in a cynical move Cinema Cosmo, underestimating the demand for Rebellious Girl, agreed to premiere Mizrahi's Qalb imra'a (Heart of a Woman, 1940) in Dagher's sixth week. However, when Rebellious Girl turned out to be a success, Mizrahi's film was bumped off the schedule. ${ }^{101}$

Over time, the studios with the greatest output and influence sought to renegotiate their terms with cinema owners, including securing exclusive contracts. ${ }^{102}$ Although the distributor of Heart of a Woman filed a lawsuit over the lost revenues, it appears that Mizrahi made peace with the owners of Cinema Cosmo. During the 1943-44 season, Studio Mizrahi films virtually monopolized Cinema Cosmo. ${ }^{103}$ Following this successful season, Mizrahi convinced Cinema Cosmo to grant him an exclusive contract for the eight films he was projected to direct or produce the coming year. For the entire 1944-45 season, Cinema Cosmo screened only films produced by the Egyptian Films Company. ${ }^{104}$

But even as this arrangement was a marker of Mizrahi's success, it also drew criticism. One somewhat unflattering picture that emerges from press coverage in the 1940 s is of Mizrahi as a hoarder of resources. During the final years of World War II, filmmakers were confronted with supply crises. In 1943 a reduction of imports due to the war, coupled with an expanding domestic industry, led to a shortage of film stock. Studio Mizrahi was one of a handful of studios to which the government distributed the scarce resource. ${ }^{105}$ When the supply crisis let up the following year, the press reported that filmmakers suffered from a lack of studio space. Mizrahi was criticized for monopolizing two studios. ${ }^{106}$

In time, Mizrahi's frustration with the lack of opportunity to innovate artistically, and his interest in the financial side of filmmaking, translated into an increasing focus on production. The 1945-46 season represented a shift in Mizrahi's career, marking his turn toward producing other directors' films. 
Anwar Wagdi, an actor who appeared in several of Mizrahi's films before launching his own career as a director, praised Mizrahi's skills as both a director and a producer. Calling Mizrahi "Egypt's number-one director," Anwar Wagdi points to Mizrahi's ability to elicit strong performances from actors who "later failed when they worked with someone else." According to Wagdi, as a prolific producer, Mizrahi wielded significant power to shape the market. However, in Wagdi's view, Mizrahi's creative directorial impulses were in constant conflict with his business interests as a producer. ${ }^{107}$

Beginning in the 1944-45 season, Mizrahi resolved this perceived conflict by turning his attention to film production. As a producer, Mizrahi supported the creative efforts of some of the leading directors in the Egyptian film industry. Mizrahi's Egyptian Films Company produced Yusuf Wahbi's Ibn al-haddad (Son of a Blacksmith, 1944), Al-Fanan al-'́azim (The Great Artist, 1945), and Yad Allah (Hand of God, 1946); Niyazi Mustafa's Shari' Muhammad Ali (Muhammad 'Ali Street, 1944); Kamal Salim's Al-Mazahir (Manifestations, 1945); and Husayn Fawzi's Aksbris al-hubb (Love Express, 1946). Mizrahi walked a fine line as a producer of other directors' films. Mizrahi maintained that he did not interfere with the creative license of the films' directors. ${ }^{108}$ But the press criticized him for abnegating responsibility for the quality of the films that came out of his studio. ${ }^{109}$

Togo Mizrahi's training in business served him well as a producer. In 1942 Mizrahi, writing from his experience in film production, published an article addressing commercial aspects of the industry. The optimistically titled essay, "Egyptian Production Is The Most Complete Production in the World," attempts to debunk claims levied by a critic who, citing limited returns from cinemas, expressed concern about the commercial viability of the Egyptian film industry. Mizrahi counters that film production and box-office receipts were appropriately scaled for the size of the audience and number of cinemas. ${ }^{110}$

Mizrahi's article amounts to a manifesto of sorts, revealing his commitment to the growth and financial health of the Egyptian film industry: "We-people and producers-must all be soldiers in solidarity, standing shoulder to shoulder for the sake of the Egyptian film renaissance so that we can achieve, some day in the future, the perfection sought by the Egyptian people and the brotherly people who also see these films. God alone is the arbiter of success." ${ }^{\prime 11}$ Mizrahi articulates that his filmmaking efforts are part of a national project, with a Pan-Arab gloss. He grants credit for much of the success of the film industry to the audience for turning out in sufficient numbers to support local production. The essay also gives insights into Togo Mizrahi's self-characterization. He articulates a collaborative spirit and expresses humility. He also, notably, identifies himself, first and foremost, as a producer.

In 1944, director Niyazi Mustafa contracted to direct films to be produced by the Egyptian Films Company. Mustafa, a rising star of the Egyptian cinema 
industry, had a long-standing and productive relationship with Studio Misr. Mustafa shot his 1944 film Muhammad 'Ali Street at Studio Mizrahi, and returned in 1946 to undertake Malikat al-gamal (The Beauty Queen). In the middle of production, Mustafa walked off the set. Mizrahi stepped in to complete the film, which was released in April 1946 without directorial credit. The Beauty Queen was the last film Togo Mizrahi had a hand in directing. ${ }^{112}$

Later that year, Togo Mizrahi reportedly rented out his studio to Hilmi Rafla, who went on to become a prolific director. Rafla had begun his career in the 1930s as a makeup artist for theater and cinema. He worked on six productions that Mizrahi directed, starting with Layla the Schoolgirl in 1941. Rafla's directorial debut, Al-'Aql fi igaza (The Mind Is on Vacation, 1947), was shot in the studio that Togo Mizrahi had built. ${ }^{113}$

\section{THE END OF STUDIO TOGO MIZRAHI}

The exact circumstances surrounding Togo Mizrahi's withdrawal from cinema production and his departure from Egypt remain a mystery. Some of the evidence is contradictory; other sources are unreliable. As a result, there has been much speculation and innuendo, leading to the circulation of mistaken information and unsubstantiated rumors. In what follows, I piece together the available evidence about Togo Mizrahi's activities from 1946 to 1952 in an effort to understand his motives for retiring from cinema production at the age of forty-five.

In the 1930 s and 1940s, when Mizrahi was actively producing films, the cinema industry, like the local theater scene, scheduled new releases between October and May. This schedule seems to have suited Mizrahi, enabling him to travel to Italy in the summers - as related in 'Abd al-Halim Nasr's story about the filming of Doctor Farahat, and as documented in gossip columns from the 1930 . ${ }^{114}$ During one of his trips to Europe, Togo met Myriam Donato (1911-2003), a native of Taranto, Italy (fig. 7). They wed on 30 June 1938 at the Egyptian consulate in Rome. Myriam then moved to Egypt with Togo. The couple first resided in an apartment overlooking the Nile in the Doqqi neighborhood in Giza, then settling in a villa near the Pyramids sometime after $1943 .{ }^{115}$ The couple remained in Egypt for the duration of World War II, but Myriam did not adapt well to life there. ${ }^{116}$ Immediately after Germany's surrender on 8 May 1945, Mizrahi announced that he planned to travel to Italy on "important artistic business."

In the summer of 1946, Togo and Myriam took the first step toward their eventual relocation to Italy. In June 1946, Togo sent a postcard to his brother Alfred in Cairo with the words "my new villa in Rome" scrawled on the back in French. ${ }^{118}$ On the front was a photograph of the elegant villa Tre Madonne, where Togo and Myriam occupied a grand garden apartment. The villa was located in Rome's posh Parioli neighborhood, adjacent to the grounds of Villa Borghese. Although Mizrahi may have been based mostly in Italy after purchasing the villa in 1946, reports 


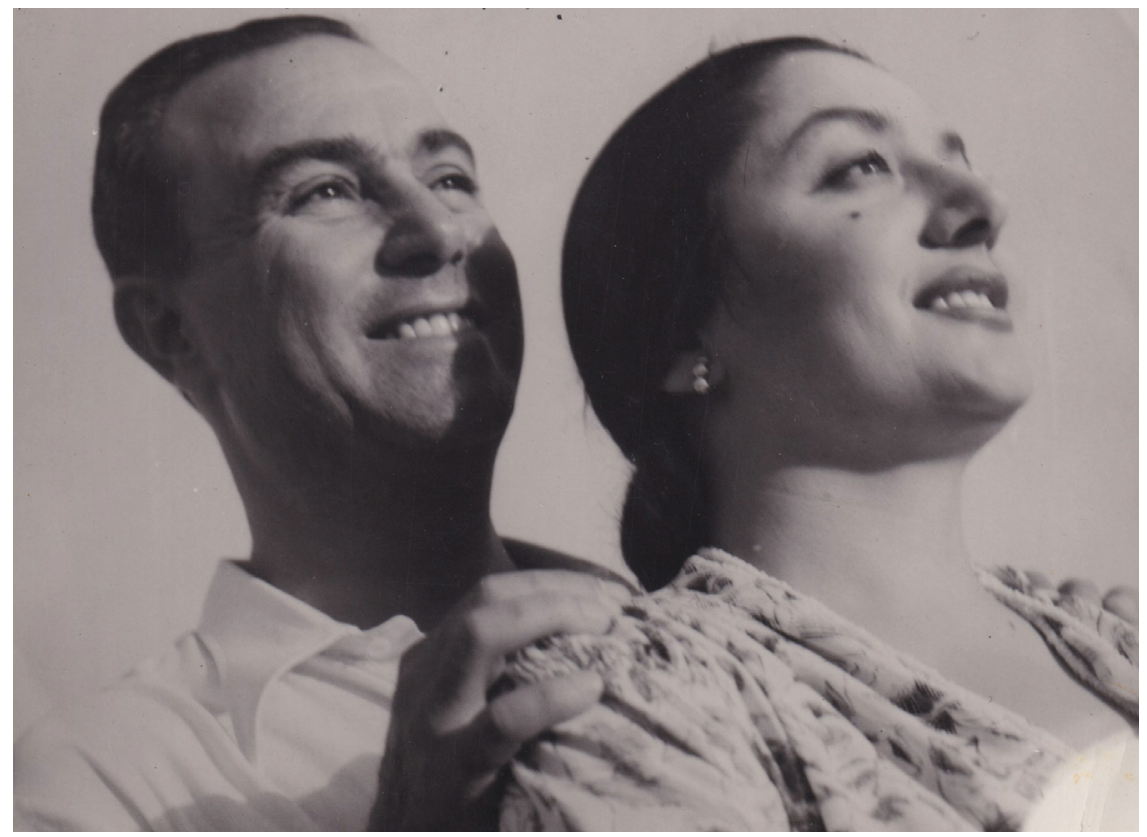

Figure 7. Togo Mizrahi and Myriam Donato Mizrahi circa 1938. Courtesy of Jacques Mizart.

of his professional activities in the ensuing years suggest that he thought it possible he might return to live and work in Egypt.

In late 1946 news broke in Egypt that an Egyptian studio was providing technical assistance for the production of Zionist films. ${ }^{119}$ Further details emerged in the 24 December 1946 issue of the Egyptian newspaper Al-Misbah, in which the Palestine correspondent reported that Togo Mizrahi had agreed to dub the films My Father's House (Herbert Kline, 1947) and Adama (Tomorrow's a Wonderful Day, Helmar Lerski, 1947) into Arabic. ${ }^{120}$ Al-Misbah was edited by a Jewish journalist, Albert Mizrahi (no relation), who, in Magdy el-Shammaa's words, engaged in a practice of "dissociation through exposure" of Zionist sympathies or collaboration. ${ }^{121}$ The article published in Al-Misbah accuses Togo Mizrahi of participating in the production and dissemination of dangerous Zionist propaganda films in Egypt. ${ }^{122}$ The accusations of Zionist sympathies and collaboration on these films could cause damage to Mizrahi's career, whether or not they had any basis in fact.

Both My Father's House and Adama were pro-Zionist films shot in Palestine. It is unlikely that the producers of the films had any intention of releasing Arabic versions of them, as Al-Misbah suggests. My Father's House was an English-language production, but some of the actors were unable to perform in English, and their dialogue required dubbing. ${ }^{123}$ Further, according to the Jewish press in Palestine, production was slowed by the lack of local technicians, so it is entirely plausible that they turned to well-established studios in Cairo for technical support. ${ }^{124}$ 
Studio Mizrahi had experience with dubbing, as did Studios Misr, al-Ahram, and Nahas. ${ }^{125}$ Without identifying the accused, the journal Al-Fanun urged the Filmmaker's Union to put a stop to this activity. ${ }^{126}$ There is some suggestion that Mizrahi was subsequently barred from producing films in Egypt. ${ }^{127}$

There has also been some speculation about the state of Togo Mizrahi's health in the late 1940s. According to one rumor, in 1945, following the release of Sallama, Mizrahi suffered a nervous breakdown and was admitted to a psychiatric hospital for treatment. ${ }^{128}$ In March 1948, a journal published a notice that Mizrahi was being treated in the Hospital for Lung Diseases in Helwan. ${ }^{129}$ Mizrahi's family disputes these claims, and denies that health concerns played any role in Mizrahi's withdrawal from the cinema industry. ${ }^{130}$

In a published statement, Togo Mizrahi attributed his withdrawal to economic challenges facing the cinema industry: "From today on, I will be a spectator. I will observe from afar the adversities suffered by Egyptian film. What crises and difficulties production companies will suffer. Some other producer, not me, will bear the responsibility. But I will not personally be the one." ${ }^{131}$ He further warned his colleagues: "[T]he producer who presses on alone to stand before this storm risks his production and his money."

Mizrahi, ever the astute businessman, caught the early signs of an industry downturn. During World War II there was a decline in the number of Hollywood films screened in Egypt, reducing the competition for Egyptian films. Rising wages in Egypt also created greater demand for movies: one source estimates that viewership grew 245 percent during the war. ${ }^{132}$ As a result, during the war the Egyptian film industry experienced unprecedented growth. Following the war, however, the industry contracted again. ${ }^{133}$ In hindsight the industry journal Al-Istudiyu praised Mizrahi's intuition and business acumen that led him to withdraw "at the appropriate moment." ${ }^{134}$

From his residence in Rome, Togo continued to follow developments in the Egyptian cinema industry. He spent three years researching and writing a screenplay for a film about Muhammad 'Ali, who ruled Egypt from 1805 to 1848. Mizrahi hoped to produce and release the film in honor the centennial of the viceroy's death. But the film was never made. ${ }^{135}$

Although Al-Sabah reported a rumor in 1948 that Mizrahi was liquidating his cinema company, ${ }^{136}$ a flurry of notes in the gossip columns the following year suggested that he was poised for a comeback. In January 1949, Al-Sabah reported that Mizrahi had agreed to direct movies produced by Nahas Films. ${ }^{137}$ Three months later, in March 1949, Anwar Wagdi was reported to be negotiating with Togo Mizrahi to direct two films for the following season. ${ }^{138}$ In September 1949, Al-Istudiyu reported that Mizrahi had hired Ibrahim Hilmi as assistant director on a planned production to be shot in Italy. ${ }^{139}$

Finally, in December 1949 Mizrahi returned to Egypt with plans to resume film production. ${ }^{140}$ In an interview with the journal Al-Istudiyu, Mizrahi revealed that 
he was preparing to direct and produce an adaptation of novel The Count of Monte Cristo by Alexandre Dumas père. He had shot some footage in Italy and had begun negotiating with actors, but had not yet signed any contracts. ${ }^{141}$ However, although a film based on the novel was released the following year, Mizrahi was not involved with the production. Kamal al-Shinawi relates that he was supposed to star in the film with Layla Murad, and that Mizrahi had contracted Behna Films for distribution. Then, Shinawi reports, "[s]uddenly, Togo traveled to Italy and abandoned the idea of the film." ${ }^{142}$ In 1950, Assia Dagher's Lotus Films released its adaptation of the novel under the title Amir al-intiqam (Prince of Vengeance), starring Anwar Wagdi and Samia Gamal, and directed by Henri Barakat. According to Shinawi, who was demoted to a supporting role in the final production, the film became "a source of conflict and an exchange of accusations" between Togo Mizrahi and the Behna brothers on one side, and Lotus Films on the other. ${ }^{143}$

The adaptation of The Count of Monte Cristo appears to have been Togo Mizrahi's last attempt at a comeback. Togo's nephew Jacques Mizart relates: “[Togo] saw that the situation had begun to deteriorate for Jews, and since he had developed relations with a number of Italian directors, he decided to go live in Rome, which pleased Myriam." ${ }^{144}$ Alfred Mizrahi, Togo's youngest brother, recalls: "He saw Cairo burning in 1952. When ashes reached his balcony [in Giza], he decided to leave Egypt." ${ }^{145}$ When it was not safe for Jews in Italy under the Fascist regime, Togo and Myriam made their home in Egypt. When the situation for Jews deteriorated in Egypt following the establishment of Israel, Togo and Myriam found refuge in Italy.

Mizrahi's travel documents concur with Alfred's recollections. On 8 February 1952, the Italian consulate in Egypt issued Mizrahi a passport identifying him as a permanent resident of Egypt (fig. 8). On 5 March 1952, Mizrahi transferred 500 Egyptian pounds from an Egyptian bank to an account in Italy. On 29 March 1952, Mizrahi set sail from Alexandria. ${ }^{146}$ In May 1952 Alfred Mizrahi was appointed the administrative director of the Egyptian Films Company, and he was charged with managing Togo and Myriam's private assets in Egypt. ${ }^{147}$

One week prior to his departure, on 21 March 1952, the Egyptian Ministry of the Interior issued Mizrahi a one-year residence permit. This permit represents the last documented evidence of Togo's residence in Egypt in the eyes of the Egyptian authorities. ${ }^{148}$ Subsequently, when Mizrahi sought to travel to Egypt-in 1955 and again in 1957-the consulate in Rome issued him short-term visas. ${ }^{149}$

In October 1961, Togo Mizrahi lost the rights to all of the films he produced. All of the assets of the Egyptian Films Company were sequestered, along with the Togo's and Alfred's personal property in Egypt. Stateless, and with no source of income and no assets, Alfred was forced to leave Egypt in 1962 and join his siblings abroad. ${ }^{150}$

On 4 July 1966, the rights to the output of the Egyptian Films Companythirty-four films in total-were sold to a buyer named Taha Za'afarani Tantawi. 


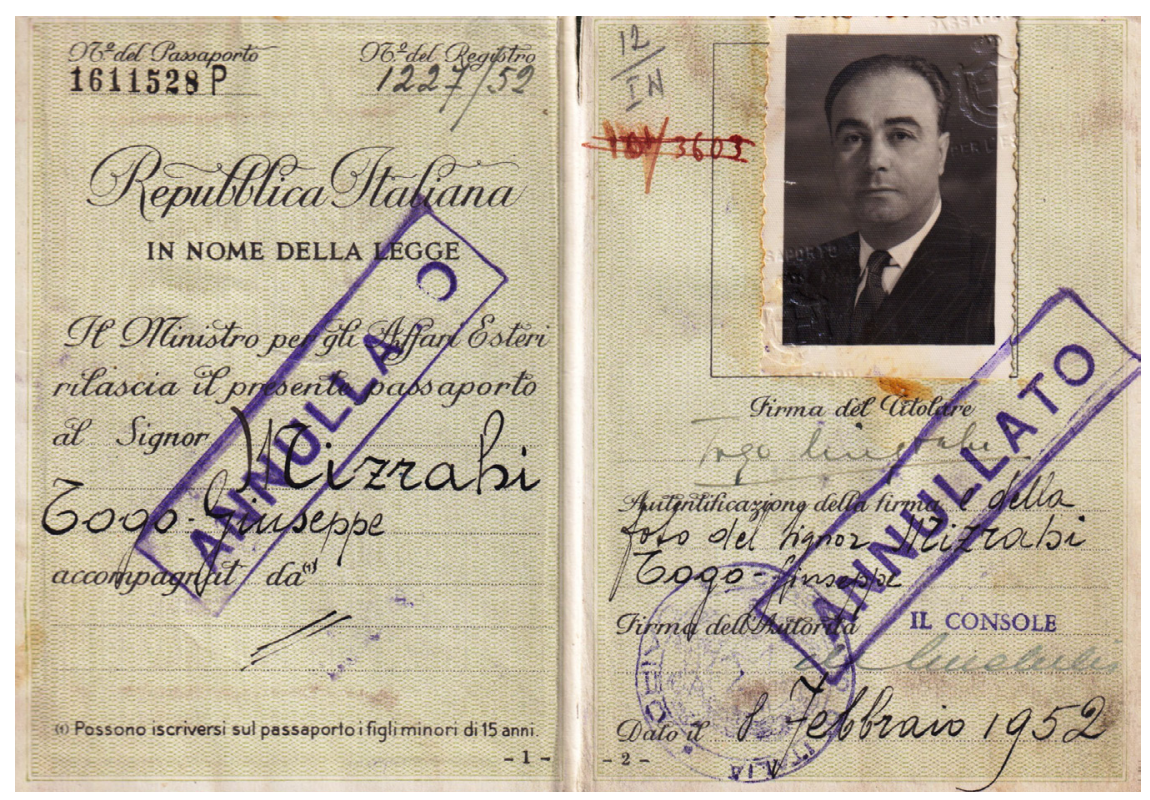

FIGURE 8. Page of the passport issued to Togo Giuseppe Mizrahi by the Italian consulate in Egypt on 8 February 1952. Courtesy of Jacques Mizart.

A letter dated 14 July 1966 from the accountant charged with liquidating the assets of the Egyptian Films Company informs Behna Films, Mizrahi’s distributor, of this transfer of property and rights per order $165 / 65$, requesting that they desist from distributing the films. ${ }^{151}$

Mizrahi remained in contact with the George and Michael Behna-and he continued to follow developments in Egyptian cinema. Shortly after the sale of the Egyptian Films Company, Mizrahi wrote to the Behna brothers to request subscriptions to the journals Al-Mussawar and Al-Kawakib. ${ }^{152}$

Togo Mizrahi continued to appeal to the Egyptian government to recuperate his films. Alfred Mizrahi developed a relationship with Anwar Sadat in the 1960s. ${ }^{153}$ In 1970, when Sadat became president of Egypt, Togo Mizrahi was optimistic that he would restore the rights to his films. But Mizrahi's hopes were never realized. The rights to all the films Togo Mizrahi directed and produced were not restored to him during his lifetime.

In Rome, Togo Mizrahi's social circle included prominent members of the film community, including producer Carlo Ponti. ${ }^{154}$ Mizrahi continued to work for several years in the Italian cinema industry as a producer and an adviser. ${ }^{155}$ His family maintains that Mizrahi stopped directing to pursue his many other interests. ${ }^{156}$ Three of Togo's sisters had married French citizens and settled in Paris. Later in life, Togo received a residence permit to live in Paris, but he never settled there 
permanently. ${ }^{157}$ Togo Mizrahi died in Rome on 5 June 1986, forty years after he stopped directing films in Egypt.

After Mizrahi's death, his estate continued to appeal for the restoration of his property. In a letter dated 23 June 1987, the Egyptian cultural attaché in Paris responded to one such request by Togo's sister Camille, stating that the films directed by Togo Mizrahi "are held in the archives of the national library, but are in very poor condition." However, he assures her that "the National Cinema Center indicates that Studio Misr possesses the negatives and could develop them upon your official request, and at your expense," adding that the cost of developing the films could not be estimated in advance. ${ }^{158}$

\section{REEVALUATING TOGO MIZRAHI'S LEGACY}

What were Togo Mizrahi's political views? In his few surviving written statements, he projects a fierce patriotism, and a commitment to developing the Egyptian film industry to promote national pride. But Mizrahi left little record of his commitments to the large political issues of the day. What Togo Mizrahi left us are his films.

In this book, I set out to unpack the implied politics of Mizrahi's film oeuvre. Mizrahi's early socially aware melodramas depict the hardships of the lower classes. This interest and awareness of income disparities in Egypt also informs Mizrahi's 1930 comedies of mistaken identity. These films, discussed in the next three chapters, map out Mizrahi's representation of Egyptian heterogeneity. Ahmad Bahjat calls Mizrahi a Zionist; ${ }^{159}$ but, as I argue in chapter 6, his film Al-Tariq al-mustaqim (The Straight Road, 1943) can be read as expressing concerns with the effect of Zionism on Jewish diaspora identity. Viola Shafik identifies Mizrahi as a royalis $\mathrm{t}^{160}$; but, as I argue in chapter 7 , his film Layla (1942) critiques the behavior of Egypt's royalty. Togo Mizrahi's legacy has been overdetermined by the assumed politics of his identity as an affluent Jewish noncitizen resident of Egypt. In my analyses that follow, I tease out the cultural and political implications of Mizrahi's films. Togo Mizrahi was a man of "work over words." I seek to let Mizrahi speak through his art. 